\title{
Biodecolourization of Textile Effluent using Mutagenised Strains of Pseudomonas and Bacillus species Isolated from Dyed Contaminated Soil.
}

\author{
John W.C., ${ }^{*}$, Anyanwu N.C.J ${ }^{2}$, Akande $\mathrm{D}^{3}$ and Ayisa T.T ${ }^{4}$. \\ ${ }^{1,2,3}$ Department of Microbiology, Ahmadu Bello University, Zaria, Nigeria. \\ ${ }^{4}$ Department of Science Laboratory Technology, Federal Polytechnic Bida, Niger State, Nigeria.
}

\begin{abstract}
This research was aimed at modification of Bacillus and Psuedomonas species isolated from dye contaminated soil with physical and chemical mutagens for improved dye biodecolourization. Textile effluent and dye contaminated soil were collected from a textile industry located at Challawa industrial area Kano, Nigeria. Bacillus cereus, Bacillus firmus, Pseudomonas aeruginosa and Pseudomonas flourescens were isolated and selected based on their biodegradation potentials of textile effluents. The Bacillus and Pseudomonas species were modified with Ultra-violet rays at $254 \mathrm{~nm}$ and Nitrous acid at different time interval $(5,10,15,20,25$ and 30mins). Ultra-Violet (UV) light irradiated strains showed percentage survival that ranged from $3.04 \%$ Bacillus cereus $\left(B 8_{U V} 30\right)$ to $56.15 \%$ Pseudomonas fluorescens $\left(P 23_{U V} 5\right.$ ). The effect of nitrous acid $\left(\mathrm{NHO}_{2} 2.0 \mathrm{M}\right)$ treatment on survival after exposure by the parent strains $\left(B 6_{W S}, B 8_{W S}, P 2_{W S}\right.$ and $\left.P 23_{W S}\right)$ at different time interval $(10,15,20,25,30$ mins) showed percentage survival ranging from $10.37 \%$ Pseudomonas fluorescens $\left(P 23_{N A} 10\right)$ to $58.76 \%$ Bacillus cereus $\left(B 8_{N A} 10\right)$. The modified strains $\left(B 8_{U V} 30\right)$ had higher textile effluent decolourization potentials of 60.30 0.04 than the parent strain $\left(B 8_{W S}\right)$ which showed $42.56 \pm 0.13 \%$ biodecolourization activities. Thus, the modified strains could be employed in the biodecolourization of textile effluents to meet acceptable levels prior to discharge of textile effluents into the receiving environment.
\end{abstract}

Keywords: UV-irradiation, nitrous acid, textile effluent, biodecolourization, Pseudomonas, Bacillus.

\section{Introduction}

Environmental problems such as appearance of colour in discharges from various industries, combined with the increasing cost of water for industrial sector, have made the treatment and reuse of effluent increasingly attractive to the industry. Textile industry is one of the oldest industries in Nigeria. Taking into account the volume and composition of effluent, the textile wastewater is rated as the most polluting among all in the industrial sector $(1,2)$.

The untreated textile wastewater can cause rapid depletion of dissolved oxygen if it is directly discharged into the surface water sources due to its high BOD value. The effluents with high levels of BOD and COD values are highly toxic to biological life. The high alkalinity and traces of chromium which is employed in dyes adversely affect the aquatic life and also interfere with the biological treatment processes (3). It induces persistent colour coupled with organic load leading to disruption of the total ecological/symbiotic balance of the receiving water stream (4).

In view of the earlier mentioned adverse effects, the textile industry effluents should be discharged after proper treatment. The dyes are stable to light, heat and oxidizing agents, and it is difficult to remove the dyes from effluents (5). This makes the effective and economic treatment of the effluents containing various dyes an important environmental problem.

Traditionally, both physical and chemical methods such as coagulation, ozonation (6), precipitation, adsorption by activated charcoal, ultrafiltration, nanofiltration (7), electrochemical oxidation, electrocoagulation $(8,9)$ were used in the treatment of the textile industrial effluents (1). But both methods have many short comings $(10,11,12)$. Chemical methods such as coagulation often produce excess amount of chemical sludge which creates problems of its disposal (13). Physical methods such as adsorption by activated charcoal often need high capital investment (14). Hence, most of the physical and chemical methods of effluent treatment are not accepted by the industries due to their high cost, low efficiency and inapplicability to a wide variety of dyes (15).

Currently, much research has been focused on the biodegradation of the industrial effluents $(10,16,17)$. It mainly shows interest towards the pollution control using bacteria, fungi in combination with physicochemical methods $(18,19)$. The biomass can absorb the chromophores and also these chromophores can be reduced into low redox potential environments (19). The attractive features of biological treatment are low cost, renewable 
and regenerative activity and little or no secondary hazard $(20,21,22)$. The conventional biological processes are not effective because the dye content in the textile effluent is toxic to the microorganisms used $(23,24)$.

In situ degradation of the effluent is a novel method under the biodegradation process. In this method, the microorganisms isolated from the site of pollution and the same microorganism can be used for the treatment of such site. Mechanical cleaning of such polluted environment could be possible but laborious, expensive, ineffective and time consuming. However, microbial degradation by natural microorganisms represents one of the mechanisms for the elimination of the pollutant from such environments, (25).

Improvement in the ability of microorganisms to degrade a pollutant could be achieved through modification of the environment or the organism. The organism can be modified through mutagenesis. Various mutagens abound and the exposure of organisms to ultra-violet (UV)-light and treatment with nitrous acid had been employed with relative success. Recent fundamental work has revealed the existence of a wide variety of microorganisms capable of decolorizing a wide variety of dyes (26). Many microorganisms belonging to different taxonomic groups of Bacteria, Fungi, Actinomycetes and Algae have been reported for their ability to decompose azo dyes (27). The Bacteria used include E coli, Bacillus spp, Clostridium spp and Pseudomonas spp. (19). The aim of the present work was to modify Pseudomonas and Bacillus species isolated from dye contaminated soil with physical and chemical mutagens for improved dye biodecolourization.

\subsection{Sample collection}

\section{Materials And Methods}

Effluent samples and soil contaminated by untreated textile waste water were collected from industrial area of Kano metropolis-Challawa Kano at the point of discharge. Samples were collected during dry season from Feburary to April. Effluent sample were collected with clean 2-littre polyethylene container twice a week for the duration of sampling. Soil samples at different locations ( $1 \mathrm{~km}$ interval) from the stream into which effluent was discharged was collected from top $4 \mathrm{~cm}$ soil profile where most of the bacterial population was concentrated. Soil sample (approximately $20 \mathrm{~g}$ ) from different locations were collected using some clean, dry and sterile polythene bags along with sterile spatula. Care was taken to see that the points of collection had widely varying characteristics as possible with regard to the organic matter, moisture content, particle size and color of soil and to avoid contamination as far as possible. The sample were labeled and transported to the laboratory using ice pack chest stored in the refrigerator at about $4^{0} \mathrm{C}$ prior to analysis.

\subsection{Isolation and screening of dye decolourizing Bacillus and Pseudomonas species.}

The dye contaminated soil sample were used for isolation of dye decolourizing bacteria. Minimal basal medium containing textile effluent as a sole source of carbon was prepared. The medium $(100 \mathrm{ml})$ in $250 \mathrm{ml}$ Erlenmeyer flask was inoculated with $10 \mathrm{ml}$ soil suspension in $100 \mathrm{ml}$ Erlenmeyer flask and incubated in orbital shaker (150rpm). After $48 \mathrm{hrs}$ of incubation, $1.0 \mathrm{ml}$ of the culture broth was appropriately diluted and plated on Nutrient and Centrimide Agar for the isolation of Bacillus and Pseudomonas species respectively. After incubation, the isolates were subcultured on nutrient agar and pure culture stocks stored at $4^{\circ} \mathrm{C}$ on nutrient agar slopes until needed. Individual colonies were characterized using Microgen biochemical test-kits and used according to the manufacturer's instructions to identify the isolates to species level.

\subsection{Mutation with UV irradiation at 254nm:}

The organisms were grown in nutrient broth for 24 hours and their microbial count was determined. Ten milliliters of broth of each organism was aseptically transferred into separate sterile Petri dishes and placed at $6 \mathrm{~cm}$ from the source of UV light, the organism was treated at intervals of 5, 10, 15, 20, 25 and 30 minutes in a dark room. The UV irradiated organisms were then transferred into a sterile twenty milliliter test tube in a dark room and treated with $0.2 \%(\mathrm{w} / \mathrm{v})$ caffeine and allowed to stand at room temperature in the dark for 5 hours. The irradiated cells were then centrifuged at 1500 rpm for five minutes, re-suspended in normal saline and recentrifuged and the supernatant used. The treated organism was incubated at $18^{\circ} \mathrm{C}$ for 16 hours and their microbial counts determined.

\subsection{Mutation with nitrous acid}

The bacterial growth was harvested from an overnight culture on nutrient broth and their microbial counts determined. The cells were subjected to nitrous acid $(0.2 \mathrm{~m}$ sodium nitrate in acetate buffer, $\mathrm{pH} 4.5)$ and treated at interval of $10 \mathrm{mins}, 15 \mathrm{mins}, 20 \mathrm{~min}, 25 \mathrm{~min}$ and $30 \mathrm{mins}$ by incubating the mixture at $30^{\circ} \mathrm{C}$. Treated cells were then centrifuged at $1500 \mathrm{rpm}$ for three to five minutes, resuspended in normal saline and re-centrifuged to remove traces of mutagen and supernatant discarded. The mutagenisd cells were then plated on nutrient agar, incubated at $37^{\circ} \mathrm{C}$ for 24 hours and microbial counts determined. 


\subsection{Biodecolourization test}

$100 \mathrm{ml}$ flask containing $50 \mathrm{ml}$ of the effluent with $2 \mathrm{~g}$ of yeast extract and $2 \mathrm{~g}$ of glucose added as a cosubstrate was prepared. The $\mathrm{pH}$ of the medium was adjusted to $7 \pm 0.2$ using phosphate buffer. The flasks were sterilized by autoclaving for $15 \mathrm{mins}$ at $121^{\circ} \mathrm{C}$. The sterilized flask containing the effluent was inoculated with $3 \mathrm{ml}$ inoculum of each test micro-organism and incubated for 5 days at room temperature on rotary shaker. An un-inoculated flask containing effluent served as control.

Optical density (OD) at $560 \mathrm{~nm}$ was determined after 5 days incubation, $10 \mathrm{ml}$ of decolourize effluent was centrifuged at $4000 \mathrm{rpm}$ for 15 minutes using laboratory centrifuge. OD was recorded spectrophotomically. The decolourization efficiency of the different isolates were calculated using the formula below.

Decolourization $(\%)=\underline{(I-F) \times 100}$

Where $I$ is the initial absorbance and $F$ is the absorbance of decolorized medium.

\subsection{Isolation and characterization of isolates}

\section{Results}

Four micro-organisms were obtained; Bacillus cereus, Bacillus firmus, Pseudomonas aeruginosa and Pseudomonas flourescens were isolated from dye contaminated soil. The biochemical characteristic are shown in tables 1 and 2

\subsection{Mutagenic treatment of the wild strain isolates.}

The effects of Ultraviolet (UV) irradiation $(254 \mathrm{~nm})$ on survival after exposure by the parent strains at different times 5,10,25,20 25 and 30, showed \% survival that range from 3.04\% Bacillus cereus (B8 $8_{\mathrm{Uv}} 30$ ) to $56.15 \%$ Pseudomonas fluorescens $\left(\mathrm{P} 23_{\mathrm{Uv}} 5\right)$. The effect of nitrous acid $\left(\mathrm{NHO}_{2} 2.0 \mathrm{M}\right)$ treatment on survival after exposure by the parent strains $\left(\mathrm{B} 6_{\mathrm{ws}}, \mathrm{B} 8_{\mathrm{ws}}, \mathrm{P} 2_{\mathrm{ws}}\right.$ and $\left.\mathrm{P} 23_{\mathrm{ws}}\right)$ at different time interval $(10,15,20,25,30)$ showed percentage survival ranging from $10.37 \%$ Pseudomonas fluorescens ( $\mathrm{P} 23_{\mathrm{NA}} 10$ ) to $58.76 \%$ Bacillus cereus $\left(\mathrm{B} 8_{\mathrm{NA}} 10\right)$.

\subsection{Biodecolourization activities by mutagenised strains}

The mutagenised strains were better decolourizer than parent strains and also UV-irradiated strains performed better than the nitrous treated strain. Bacillus cereus $\left(\mathrm{B}_{\mathrm{Uv}} 30\right)$ irradiated at 30mins and Pseudominas aerugenosa $\left(\mathrm{P}_{2} \mathrm{Uv} 20\right)$ irradiated at 20mins showed the highest percentage biodecolourization of $60.30 \pm 0.04 \%$ and $55.13 \pm 1.02 \%$ respectively while Pseudomonas fluorescens $\left(\mathrm{P} 23_{\mathrm{NA}} 30\right)$ and Bacillus firmus $\left(\mathrm{B}_{\mathrm{NA}} 30\right)$ treated with nitrous acid at $30 \mathrm{mins}$ showed $53.09 \pm 0.73 \%$ and $47.06 \pm 2.14$ respectively.

Table 1: Characterization of Pseudomonas isolates

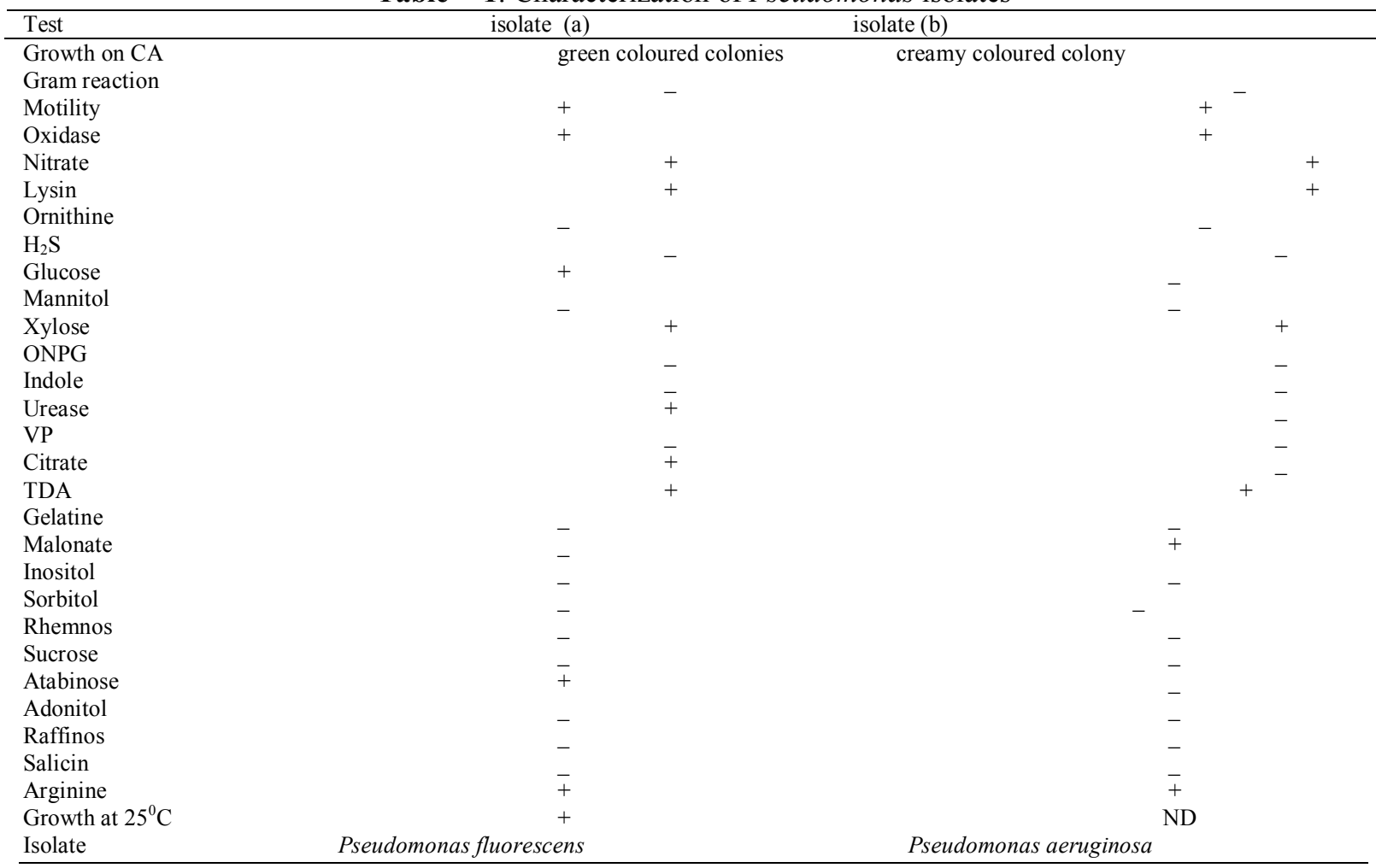


Key: + = Positive; - = Negative; ND = Not Determined; ONPG = O-nitrophenyl- $\beta$-D-galactopyranoside; VP = Vogas proskauer; TDA = Tyrosine-D-arginine; $\mathrm{CA}=$ Centrimide Agar.

Table 2: Characterization of Bacillus isolates

\begin{tabular}{|c|c|c|c|c|}
\hline \multirow{2}{*}{$\begin{array}{l}\text { Test } \\
\text { Growth on nutrient agar }\end{array}$} & \multicolumn{2}{|c|}{12 isolate (c) 24} & \multicolumn{2}{|c|}{12 isolate (d) 24} \\
\hline & \multicolumn{2}{|c|}{ White dry colonies } & \multicolumn{2}{|c|}{ Gray dry colonies } \\
\hline Gram reaction & \multicolumn{2}{|c|}{+} & \multicolumn{2}{|c|}{+} \\
\hline Catalase & \multicolumn{2}{|l|}{+} & \multicolumn{2}{|l|}{+} \\
\hline Motility & \multicolumn{2}{|l|}{+} & \multicolumn{2}{|l|}{+} \\
\hline Arabinose & - & - & - & - \\
\hline Cellebrose & - & - & - & - \\
\hline Inisitol & - & - & - & - \\
\hline Mannitol & - & - & - & - \\
\hline Mannose & - & - & - & - \\
\hline Raffinose & - & - & - & - \\
\hline Rhamnose & - & - & - & - \\
\hline Salicin & - & - & + & + \\
\hline Sorbitol & - & - & - & - \\
\hline Sucrose & - & - & - & - \\
\hline Trehalose & - & - & + & + \\
\hline Xylose & - & - & - & - \\
\hline Adonitol & - & - & - & - \\
\hline Galactose & - & - & - & - \\
\hline MON & - & - & - & - \\
\hline MDG & - & - & - & - \\
\hline Inulin & - & - & - & - \\
\hline Melezitose & - & - & - & - \\
\hline Indole & ND & + & ND & - \\
\hline ONPG & + & + & + & + \\
\hline Arginine & - & - & - & - \\
\hline Citrate & - & - & - & - \\
\hline Voges proskauer & ND & + & ND & + \\
\hline Nitrate & ND & + & ND & + \\
\hline Isolates & Bacil & & Bacil & \\
\hline
\end{tabular}

Key: $+=$ Positive; - = Negative; ND $=$ Not determined ONPG $=$ O-nitrophenyl- $\beta$-D-galactopyranoside. $\mathrm{MON}=$ Methyl-O-Mannoside; MDG = Methyl-D-Glucoside .

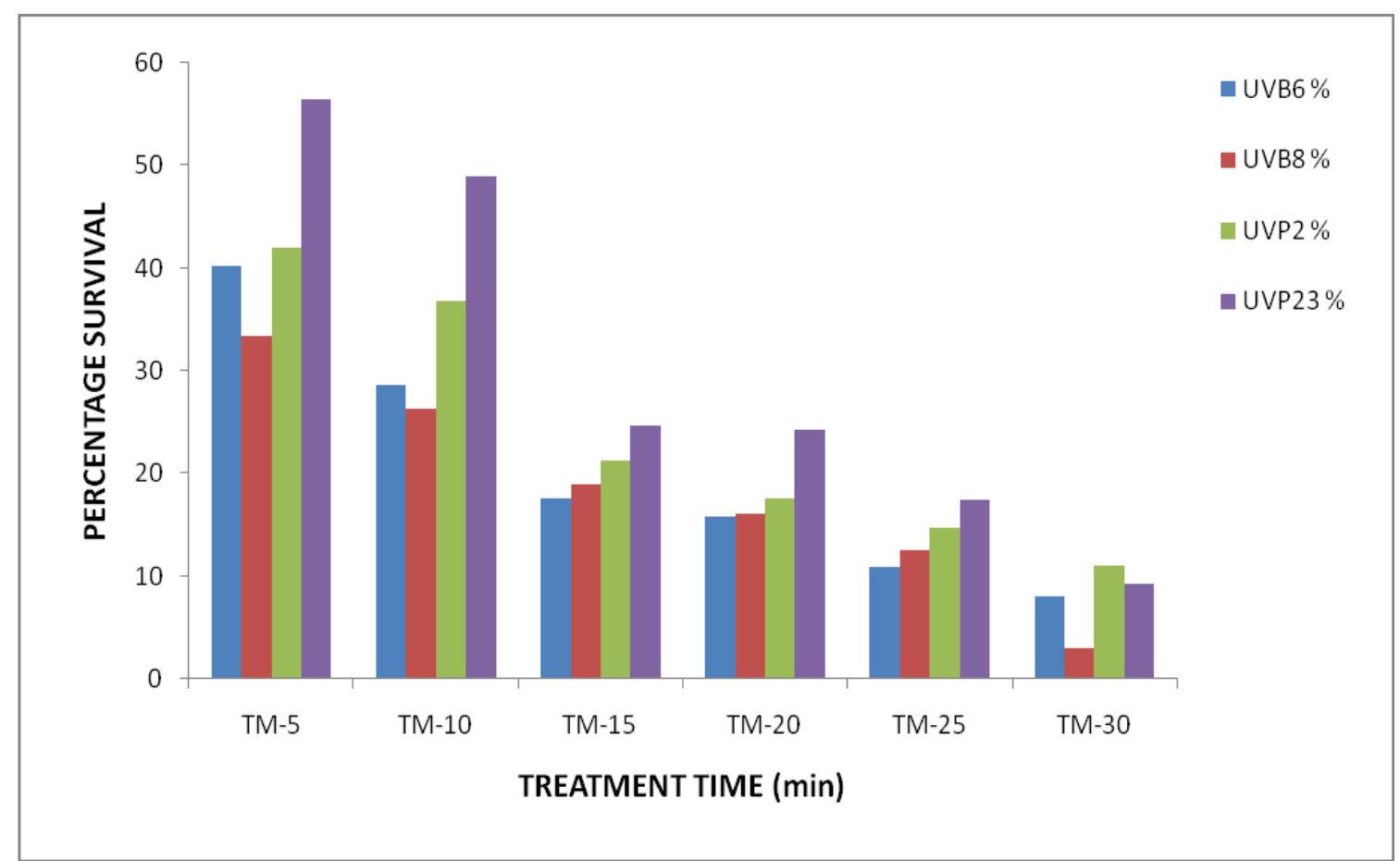

Fig 1: Survival rate of the UV-irradiated wild strains (ws) of Pseudomonas and Bacillus spp.

Key: UVB8 = UV-irradiated Bacillus cereus; UVP2 = UV- irradiated Pseudomonas aeruginosa; UVB6= UVirradiated Bacillus firmus; UVP23= UV- irradiated Pseudomonas fluorescens. 


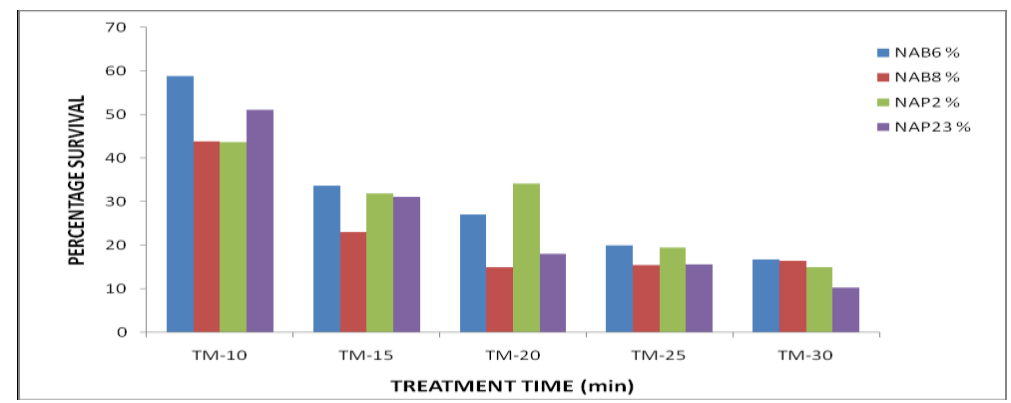

Fig 2: Survival rate of nitrous acid treated wild strains (ws) of Pseudomonas and Bacillus spp.

Key: NAB8 = Nitrous acid treated Bacillus cereus; NAP2 = Nitrous acid treated Pseudomonas aeruginosa; NAB6= Nitrous acid treated Bacillus firmus; NAP23= Nitrous acid treated Pseudomonas fluorescens .

Table 3: Mean percentage biodecolourization performance by wild strains of the Isolates.

\begin{tabular}{ll}
\hline Strains & $\begin{array}{l}\text { Biodecolourization of textile } \\
\text { effluents (\%) }\end{array}$ \\
\hline $\mathrm{B} 8_{\mathrm{ws}}$ & $42.56 \pm 0.23$ \\
$\mathrm{P} 2$ ws & $40.43 \pm 1.24$ \\
$\mathrm{~B} 6_{\mathrm{ws}}$ & $39.31 \pm 0.56$ \\
$\mathrm{P} 23_{\mathrm{wS}}$ & $36.01 \pm 2.71$ \\
\hline
\end{tabular}

Key: Ws = Wild strain; $\mathrm{B} 8=$ Bacillus cereus; $\mathrm{P} 2=$ Pseudomonas aeruginosa $; \mathrm{B} 6=$ Bacillus $\quad$ firmus; $\mathrm{P} 23=$ Pseudomonas fluorescens.

Table 4: Mean percentage biodecolourization performance by mutagenized strains

\begin{tabular}{ll}
\hline Strains & Biodecolourization of textile effluent (\%) \\
\hline $\mathrm{B} 8_{\mathrm{UV}} 30$ & $60.30 \pm 0.04$ \\
$\mathrm{P} 2_{\mathrm{UV}} 20$ & $55.13 \pm 1.02$ \\
$\mathrm{P} 23_{\mathrm{NA}} 30$ & $53.09 \pm 0.73$ \\
$\mathrm{~B} 6_{\mathrm{NA}} 30$ & $47.06 \pm 2.14$ \\
\hline
\end{tabular}

Keys: $\mathrm{B} 8_{\mathrm{Uv}} 30=\mathrm{UV}$-irradiated Bacillus cereus, $\mathrm{P} 2_{\mathrm{UV}} 20=\mathrm{UV}$-irradiated Pseudomonas aeruginosa, $\mathrm{P} 23_{\mathrm{NA}} 30=$ Nitrous acid treated Pseudomonas fluoresens, B6 ${ }_{\mathrm{NA}} 30=$ Nitrous acid treated Bacillus firmus, 30 and $20=$ Time of exposure to mutagens, $\pm=$ Standard error.

\section{Discussion}

The isolation of Bacillus and Pseudomonas species from the textile effluent contaminated soil confirms the reports of previous studies Murugalatha et al, (28) that organism capable of utilizing dye could be isolated from textile effluent. The result of treatment of the wild strains with ultraviolet irradiation and the nitrous acid treatment indicated that the increase in duration of the exposure of the organisms to the mutagen is directly proportion to the increase in rate of biodecolourization activities of the organisms. This study disagrees with the previous work by Ado et al., (29) which state that it is not directly proportional. However, low survival rate after exposure to UV-light and nitrous acid appeared to be related to the increase in biodegradation potential of the isolates. Mutant strains $\mathrm{B}_{\mathrm{UV}} 30$ obtained after 30 minutes irradiation with a percentage survival of $3.00 \%$ gave the highest biodegradation of $60.30 \pm 0.04 \%$. This finding is in agreement with the observation of Ado (29) that for a mutagenic agent to be successful, it should have a high rate of kill. Biodecolourization activities of the wild strains were enhanced by genetic improvement of the organisms using mutation technique. The technique has been widely employed to obtain strains with desired characteristics (30). This was achieved by a combination of physical and chemical mutagens using ultraviolet irradiation and nitrous acids. The isolates Bacillus species and Pseudomonas species were susceptible to mutation with UV-light irradiation and nitrous acid treatment. This showed that they were not defective in nucleotide excision repair (NER) endonucleases (31). Hence they were UV-light and nitrous acid sensitive and were employed as subject for further studies on mutation and recombination. The improved quality of textile effluent observed during this study after introduction of mutant strains into it is attributed to mutation of parent strains. This corroborates the reports of previous studies by $(25,29,32)$. The results of the treatment of the textile effluent with mutagenized strains revealed biodecolourization ability of $60.30 \pm 0.04 \%$. This attests to the efficacy of chemical and physical mutagens as tools for genetic improvement of biodegradation abilities of micro-organisms. This results are in agreement with the findings of other workers who also used chemical and physical mutagens to obtain hyper biodecolourizing mutant strains $(31,33)$. Textile effluent biodecolourization activities revealed that mutants were better dye degraders than the parent strains. 


\section{Conclusion}

Mutant strains were found more capable in decolourizing the textile effluents than the parent ones. Hence, the genetic improvement and manipulation of textile effluent biodecolourization enzyme could remediate textile effluent treatment and its public health challenges.

\section{References}

[1]. M. Vilaseca, M.C. Gutierrez, V. Lopez-Grimau, M. Lopez-Masas, and M. Crespi, Biological treatment of a textile effluent after electrochemical oxidation of reactive dyes, Water Environment Research, 82, 2010, 2.

[2]. J.A. Awomeso, A.M. Taiwo, A.M. Gbadebo and J.A. Adenowo, Studies on the pollution of waterbody by textile industry efluents in Lagos, Nigeria, Journal of Applied Sciences Environment Sanitary Sby. 5, 2010, 353-359

[3]. Brown, A. Mark and C. Stephen, Predicting Azo Dye toxicity, Environmental Science Technology, 23, 1983, 249-324

[4]. N. Puvaneswari, J. Muthukrishna and P. Gunasekaran, Toxicity Assessment and Microbial Degradation of Azo Dyes, Indian Journal of Experimental Biology, 44, 2006, 618-626.

[5]. G.. B. Adebayo, G.. A Otunola, and T.A Ajao, Assessment and biological treatment of effluent from textile effluent, African Journal of Biotechnology, 8(18), 2009, 30.

[6]. S.H. Lin and C.H. Lin, Treatment of textile wastewater by ozonation and chemical coagulation, Water Research, 27, 1993, 1743 1748 .

[7]. A. Akbari, S. Desclaux, J.C. Remigy and P. Aptel, Treatment of textile dye effluents using a new photografted nanofiltration membrane. Desalination, 2002, 149

[8]. M. Kobya, O.T. Can and M. Bayramoglu, Treatment of textile wastewaters by electrocoagulation using iron and aluminum electrodes, Journal of Hazard Material, B100, 2003, 163-178.

[9]. A. Alinsafi, M. Khemis, M.N. Pons, J.P Leclere A. Yaacoubi, A. Benhammou and A. Nejmeddine, Electro-coagulation of reactive textile dyes and textile wastewater, Chemical Engineering Process, 44, 2005, 461-470.

[10]. S. Andleed, N. Atig, R.R. Hussnain, M. Shafique, B. Ahmad, P.B. Ghumro, M. Hussnain, A. Hameed and S. Ahmad, Biological treatment of textile effluent in stirred tank bioreactor. International Journal of Agricultural Biology, 12, 2010, 256-260.

[11]. J.P. Lorimer, T.J. Mason, M. Plattes, S.S. Phull and D.J. Walton, Degradation of dye effluent, Pure and Applied Chemistry, 73, 2001, 1957-1968.

[12]. R. Babu, A.K. Parande, S. Raghu and T.P. Kumar, Cotton Textile Processing: Waste Generation and Effluent Treatment, Journal of Cotton Science, 11, 2007, 141-153.

[13]. O.U. Ezeronye, N.U. Asamudo and A.S. Daba, Bioremediation of textile effluent using Phanerochaete chrysosporium, African Journal of Biotechnology, 4 (13), 2010, 1548-1553

[14]. K.T. Chung and S.E.J. Steven, Degradation of Azo dyes by environmental Microorganisms and helminthes. Environmental Toxicology Chemistry 12, 1993, 2132-2132.

[15]. J. Kalyanee, N. Rujikan, N. Jongjira, and C. Boonsiri, Decolorization and degradation of C I Reactive Red 195 by Enterobacter species. Thammasat International Journal of Science Technology, 12(4), 2007.

[16]. Z. Sapc and B. Ustun, The Removal of Color and Cod from Textile Wastewater by using Waste Pumice. Electronic Journal of Environmental, Agricultural and Food Chemistry, 2, 2003, 286290.

[17]. R.M. Melgoza, A. Cruz and G.. Buitron, Anaerobic/Aerobic Treatment of Colorants Present in Textile Effluents, Water Science Technology, 50, 2004, 149- 155

[18]. M.I. Beydilli, S.G. Pavlostathis and W.C. Tincher, Decolorization and toxicity screening of selected reative azo dyes under methanogenic conditions, Water Science Technology, 38, 1998, 225-232.

[19]. G., McMullan, C. Meehan, A. Coneely, N. Kirby, T. Robinson, P. Nigan, I.M. Banat, R. Marchant and W.F. Symth, Microbial decolorization and degradation of textile dyes, Applied Microbiology Technology, 56, 2001, 81- 87.

[20]. R.E. McKinney and J.T. Pleffer, Effect of Biological Waste Treatment on Water Quality, American Journal of Public Health, 55, 1965, 772-781.

[21]. M.K. Sharifi, C. Azimi and Khalili, Study of the Biological Treatment of Industrial Waste Water by the Activated Sludge Unit, 2001 .

[22]. J.L. Morias and P.P. Zamora, Use of advanced oxidation process to improve the biodegradability of mature landfill leachate, Journal of Hazard Material, 123, 2005, 181-186.

[23]. T.H. Kim, C. Park, J. Lee, E.B. Shin and S. Kim, Pilot scale treatment of textile wastewater by combined process (fluidized biofilm process chemical coagulation- electrochemical oxidation), Water Research, 36, 2002, 3979-3988.

[24]. M. Koch, A. Yediler, D. Lienert, G.. Insel and A. Kettrup, Ozonation of hydrolyzed azo dye reactive yellow 84 (CI), Chemosphere, 46, 2002, 109-113.

[25]. O.E. Idise, J.B. Ameh, S.E. Yakubu and C.A. Okuofo, Modification of Bacillus cereus and Pseudomonas aeruginosa isolated from a petroleum refining effluent for increased petroleum product degradation. African Journal of Biotechnology, 9(22), 2010.

[26]. R. Leena and D. Selva Raj, Biodecolourization of textile effluent containing reactive black-B by effluent adapted and non adapted bacteria, African Journal of Biotechnology,7 (18), 2008, 3309-3313.

[27]. O.D. Olukanni, A.A. Osuntoki and G..O. Gbenle, Textile effluent biodegradation potentials of textile effluent- adapted and non adapted, 2006.

[28]. N. Murugalatha, A. Mohankumar, Rajestic and A. Sankaravadiro, Textile effluent treatment by Bacillus species isolated from processed food. African Journal of Microbiology Research, 20, 2010, 2122-2126.

[29]. S. A. Ado, Studies on genetic improvement of Aspergillus niger - CAS for amylase production. PhD thesis, Department of Microbiology, Ahmadu Bello University, Zaria, June 2004.

[30]. A. Pandev, P. Singh and L. Iyengar, Bacterial decolorization and degradation of a 20 dyes. International Biodeterioration and Biodegradation, 59 (4), 2000, 479-491.

[31]. J.D. VanHamme, A. Singh and O.P. Wad, Recent advances in Petroleum microbiology. Molecular Biology. 67 (4), $2003,503-549$.

[32]. WHO, Water pollutants, biological agents, dissolved chemicals non dissolved chemicals, sediments, heat, WHO ceha, amma, Jordan, 2002.

[33]. P.O. Okerentugba and O.U. Ezeronye, Petroleum degrading potentials of single and mixed microbial cultures isolated form rivers and refinery effluent in Nigeria. African Journal of Biotechnology, 2 (9), 2003, 288-292 